\title{
Acinetobacter indicus sp. nov., isolated from a hexachlorocyclohexane dump site
}

\author{
Correspondence \\ Rup Lal \\ ruplal@gmail.com
}

\author{
Jaya Malhotra, Shailly Anand, Swati Jindal, Raman Rajagopal and Rup Lal \\ Department of Zoology, University of Delhi, Delhi 110007, India
}

The genus Acinetobacter was established in 1954 by Brisou \& Prevot (1954). Species belonging to this genus have been largely reported from water, soil and even from human skin samples. At the time of writing, this genus included 32 genomic species (Bouvet \& Grimont, 1986; Bouvet \& Jeanjean, 1989; Tjernberg \& Ursing, 1989; Gerner-Smidt \& Tjernberg, 1993; Vaneechoutte et al., 1999; Nemec et al., 2001; Carr et al., 2003; Nemec et al., 2003), of which 26 have validly published names (www.bacterio.cict.fr/a/ acinetobacter.html). Members of the genus Acinetobacter are non-motile, strictly aerobic, oxidase negative, catalase positive and Gram-negative coccobacilli. Other characteristics include their ability to utilize a diverse range of compounds as sources of carbon and to grow on minimal salt medium.

We are studying the microbial diversity at a hexachlorocyclohexane $(\mathrm{HCH})$ dump site that was created as a result of the disposal of $\alpha$ - and $\beta$ - $\mathrm{HCH}$ ( $\mathrm{HCH}$ waste left out after

Abbreviations: $\mathrm{HCH}$, hexachlorocyclohexane; $\mathrm{ML}$, maximum likelihood; NJ, neighbour-joining; Q-9, ubiquinone.

The GenBank/EMBL/DDBJ accession numbers for the 16S rRNA and partial rpoB gene sequences of strain $A 648^{\top}\left(=\mathrm{DSM} 25388^{\top}=\mathrm{CCM}\right.$ $7832^{\top}$ ) are HM047743 and JF772169, respectively.

Four supplementary figures and two supplementary tables are available with the online version of this paper. the purification of lindane) on barren land located at Ummari village, Lucknow, India (Jit et al., 2011). Several bacteria have been isolated from this dump site. Over the past 5 years, we have been characterizing bacterial strains from this site to augment our efforts to develop bioremediation technology. So far we have characterized 15 novel species from this $\mathrm{HCH}$ dump site and these studies indicate that over the past few years the microbial community at the dump site has been drastically altered as a result of the presence of $\mathrm{HCH}$ waste, giving rise to bacterial strains that either degrade or tolerate very high levels of $\alpha$ - and $\beta-\mathrm{HCH}$ isomers. Both these $\mathrm{HCH}$ degraders and non-degraders seem to play an important role in depleting the $\mathrm{HCH}$ isomer levels at these sites (Lal et al., 2010).

In the present investigation, a bacterial strain, $\mathrm{A} 648^{\mathrm{T}}$, was isolated from soil samples collected from this $\mathrm{HCH}$ dump site. This strain was isolated by plating a serially diluted soil sample on Luria-Bertani (LB) plates. For this, $1 \mathrm{~g}$ soil was inoculated in $9 \mathrm{ml}$ minimal salt medium and incubated for 4 days, from which $100 \mu \mathrm{l}$ was plated on LB agar containing: $10 \mathrm{~g}$ tryptone $1^{-1}, 5 \mathrm{~g}$ yeast extract $1^{-1}, 5 \mathrm{~g} \mathrm{NaCl} 1^{-1}$, $1 \mathrm{~g}$ glucose $1^{-1}$ and $15 \mathrm{~g}$ agar $1^{-1}$. After $24 \mathrm{~h}$ incubation at $28^{\circ} \mathrm{C}$, a yellow-coloured colony appeared that was picked and purified by repeated streaking on LB agar. The taxonomic position of strain $\mathrm{A} 648^{\mathrm{T}}$ was determined by 
using a polyphasic approach (Kumar et al., 2008; Jit et al., 2008; Singh \& Lal, 2009). On the basis of phylogenetic, genotypic and phenotypic characteristics, strain $\mathrm{A} 648^{\mathrm{T}}$ was found to represent a novel species of the genus Acinetobacter.

The 16S rRNA gene sequence of strain $\mathrm{A} 648^{\mathrm{T}}$ was amplified using the $8 \mathrm{~F}\left(5^{\prime}\right.$-AGAGTTTGATCCTGGCTCAG- $\left.3^{\prime}\right)$ and 1542R (5'-AAGGAGGTGATCCAGCCGCA-3') universal primer set by colony PCR (Kumar et al., 2008). The PCR product was purified using a Gel Extraction kit (Nucleospin Extract II, MACHEREY-NAGEL), according to the manufacturer's instructions. The eluted DNA fragment was then directly sequenced by the dideoxy chain-termination method using the 3100 Avant Genetic Analyzer (Applied Biosystems). The 16S rRNA gene sequence obtained was manually checked and aligned using SEQUENCING ANALYSIS 5.11 and CLONE MANAGER 5. A continuous stretch of $1393 \mathrm{bp}$ of the $16 \mathrm{~S}$ rRNA gene sequence was obtained and used to search for similarity using the sequence match tool of Ribosomal Database Project II (http://rdp.cme.msu.edu/seqmatch/seqmatch intro.jsp), the BLAST program of the National Centre for Biotechnology Information (http://www.ncbi.nlm.nih.gov) and the EzTaxon server (http://www.eztaxon.org/; Chun et al., 2007). A preliminary sequence comparison with the $16 \mathrm{~S}$ rRNA gene sequences deposited in the GenBank database indicated that strain $\mathrm{A} 648^{\mathrm{T}}$ belonged to the genus Acinetobacter. The sequence similarity was calculated as the nucleotide differences between the 16S rRNA gene of $\mathrm{A} 648^{\mathrm{T}}$ and those of the other members of the genus. The search revealed that the nearest neighbours of strain $\mathrm{A} 648^{\mathrm{T}}$ are Acinetobacter radioresistens DSM 6976 ${ }^{\mathrm{T}}$ (97.6\%), A. venetianus ATCC $31012^{\mathrm{T}}$ (97.5\%), A. baumannii LMG $1041^{\mathrm{T}}(97.4 \%)$, A. parvus LMG $21765^{\mathrm{T}}(97.4 \%)$, A. junii LMG $998^{\mathrm{T}}(97.3 \%)$ and A. soli JCM $15062^{\mathrm{T}}(97.0 \%)$. For the construction of the phylogenetic tree, almost full-length $16 \mathrm{~S}$ rRNA gene sequences of all the recognized species and some other strains assigned to the genus Acinetobacter were retrieved from the GenBank database. These sequences were aligned using the CLUSTAL_X program (Thompson et al., 1997), and the 16S rRNA gene sequence of Psychrobacter immobilis ATCC 43116 ${ }^{\mathrm{T}}$, which showed $89 \%$ sequence similarity with $\mathrm{A}_{648}{ }^{\mathrm{T}}$, was used as the out-group. To elucidate the phylogenetic relationship between the novel isolate and the other species of the genus Acinetobacter, the neighbour-joining (NJ) method of Saitou \& Nei (1987) (Fig. 1) and maximum-likelihood (ML) (Takahashi \& Nei, 2000) (Fig. S1, available in IJSEM Online) methods were used in the PHYLIP package (Felsenstein, 1993). The phylogenetic tree was analysed by using the TreeView program (Page, 1996). The resultant tree topology was inferred using bootstrap analysis (Felsenstein, 1981) based on 1000 resamplings. The evolutionary distance matrix was generated using the distance model of Jukes \& Cantor (1969). The 16S rRNA gene sequence analysis showed the affiliation of strain $\mathrm{A} 648^{\mathrm{T}}$ to the genus Acinetobacter. This result was supported by the tree constructed using the ML method, where strain $A 648^{\mathrm{T}}$ clustered among members of the genus Acinetobacter. Thus, the phylogenetic tree also confirmed the observation that strain $\mathrm{A} 648^{\mathrm{T}}$ belongs to the genus Acinetobacter.

The delineation of a novel species within the genus Acinetobacter is difficult (Nowak \& Kur, 1996) and hence, in addition to the 16S rRNA gene analysis, rpoB gene sequence analysis has been demonstrated to be useful (La Scola et al., 2006). To confirm the relatedness of strain $\mathrm{A} 648^{\mathrm{T}}$ to the genus Acinetobacter, and its separation from all recognized members of this genus, comparative sequence analysis of the RNA polymerase $\beta$-subunit ( $r p o B$ ) gene was performed according to the method of La Scola et al. (2006) and Nemec et al. (2009), using two sets of primers to amplify two variable regions of the $r p o B$ gene. Zone 1 spans nucleotide positions 2916-3267 [primers Ac696F (5'TAYCGYAAAGAYTTGAAAGAAG-3') and Ac1093R (5'CMACACCYTTGTTMCCRTGA-3')], and zone 2 spans nucleotide positions 3263-3773 [primers Ac1055F (5'GTGATAARATGGCBGGTCGT-3') and Ac1598R (5'-CGBGCRTGCATYTTGTCRT-3')]. Sequencing analyses were carried out with a BigDye Terminator cycle sequencing kit (Applied Biosystems) and an ABI Prism 3100 Genetic Analyzer. Partial sequences for the $r p o B$ gene of strain $\mathrm{A} 648^{\mathrm{T}}$, the type strains of recognized species of the genus and other strains assigned to this taxon were used for the construction of the phylogenetic trees. These sequences were aligned using the coding reading frame with CLUSTAL_X (Thompson et al., 1997). The trees were constructed as described earlier. The Jukes-Cantor algorithm was used to calculate the evolutionary distances (Jukes \& Cantor, 1969). The calculations were carried out for concatenated zones 1 and 2 using nucleotide positions 2917-3267 for zone 1 and positions $3322-3723$ for zone 2 . The position numbers correspond to those of the rpoB-encoding sequence of $A$. baumannii (La Scola et al., 2006). The phylogram for concatenated $r p o B$ zones 1 and 2 is shown in Figs 2 and S2. The interspecies similarity values of strain $\mathrm{A} 648^{\mathrm{T}}$ with other members of the genus ranged from 86.6 to $81.4 \%$, which is supported by the previous findings of Nemec et al. (2010). The similarity values based on the amino acid analysis varied between 95.1 and $88.5 \%$. The resulting tree, using both the $\mathrm{NJ}$ and ML methods, as well as the amino acid sequence analysis, depicted that strain $\mathrm{A} 648^{\mathrm{T}}$ forms a distinct lineage within the genus Acinetobacter. The conclusion drawn from the phylogenetic tree of the 16S rRNA gene was supported by the comparative analysis of the $r p o B$ gene, that is, that strain $\mathrm{A}_{648}{ }^{\mathrm{T}}$ is a novel species of the genus Acinetobacter.

For DNA-DNA hybridization studies, the genomic DNA of six type strains that showed 16S rRNA gene sequence similarity greater than $97 \%$ was isolated and purified. The DNA-DNA hybridization was carried out by the membrane filter method, as explained by Kumar et al. (2008). The results of DNA-DNA hybridization were expressed as the percentage of DNA relatedness (values \pm SDs are presented in Table S1). Each value was the mean of four 


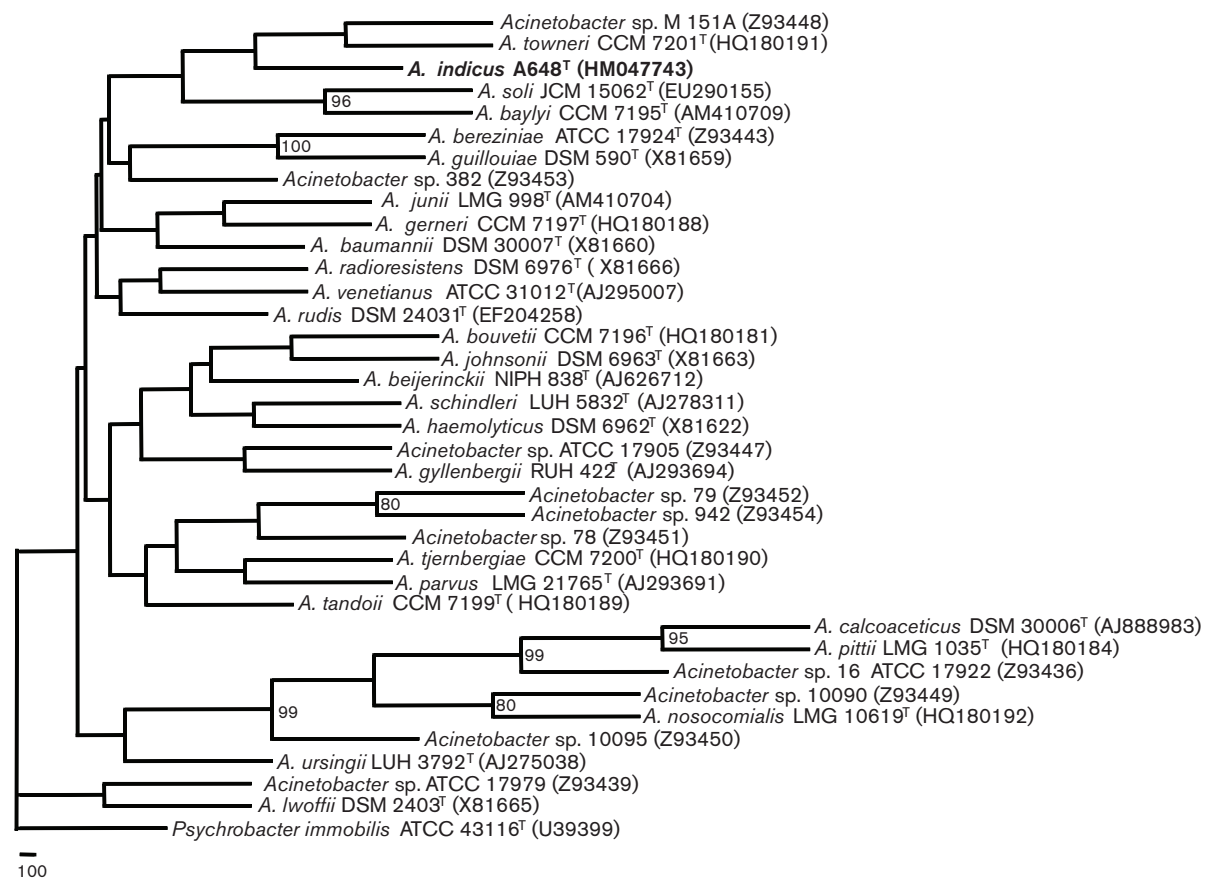

Fig. 1. Phylogenetic tree based on nearly complete $16 \mathrm{~S}$ rRNA gene sequences showing the relationship of strain $A_{648}{ }^{\top}$ with the other members of the genus Acinetobacter. P. immobilis ATCC $43116^{\top}$ (GenBank accession no. U39399) was used as the out-group. The tree was constructed using the NJ method. The numbers at nodes represent bootstrap values (based on a resampling of 1000). Bootstrap values $>70 \%$ are indicated. The GenBank accession numbers for the 16S rRNA gene sequences of each reference species are listed in parentheses. Bar, 0.01 nucleotide substitutions per site.

replicates. The DNA-DNA relatedness values between strain $\mathrm{A} 648^{\mathrm{T}}$ and its nearest neighbours were found to be less than $8 \%$, (7.3\% with $A$. radioresistens DSM $6976^{\mathrm{T}}$, $6.9 \%$ with $A$. venetianus ATCC $31012^{\mathrm{T}}, 6.0 \%$ with $A$. baumannii LMG $1041^{\mathrm{T}}, 5.5 \%$ with $A$. parvus $\mathrm{LMG} 21765^{\mathrm{T}}$, $3.8 \%$ with $A$. junii $\mathrm{LMG} 998^{\mathrm{T}}$ and $2.5 \%$ with $A$. soli $\mathrm{JCM}$ $\left.15062^{\mathrm{T}}\right)$. As the DNA-DNA hybridization values were below the threshold value $(70 \%)$ that has been recommended for the delineation of a species (Wayne et al., 1987; Stackebrandt \& Goebel, 1994), strain $\mathrm{A} 648^{\mathrm{T}}$ represents a novel species of the genus Acinetobacter.

Fatty acid methyl ester (FAME) analysis of strain $A 648^{\mathrm{T}}$ and six recognized species of the genus that are the nearest neighbours of strain $\mathrm{A} 648^{\mathrm{T}}$, namely A. radioresistens DSM $6976^{\mathrm{T}}$, A. venetianus ATCC $31012^{\mathrm{T}}$, A. baumannii LMG $1041^{\mathrm{T}}$, A. parvus LMG $21765^{\mathrm{T}}$, A. junii LMG $998^{\mathrm{T}}$ and $A$. soli JCM $15062^{\mathrm{T}}$, was carried out. All strains were grown on $\mathrm{LB}$ agar medium at $28{ }^{\circ} \mathrm{C}$ for $24 \mathrm{~h}$, then sent to Disha Institute of Biotechnology, Ahmadabad, India, for fatty acid analysis. At the Disha Institute, the cultures were revived on trypticase soy broth agar (TSBA) and grown for $24 \mathrm{~h}$, after which cultures from the third quadrant were picked and then subjected to fatty acid analysis. FAMEs were analysed from 2-4 loops of inoculum scraped from a Petri dish and subjected to saponification, methylation and extraction using the methods of Miller (1982) and
Kuykendall et al. (1988). The FAME mixtures were separated using the Sherlock Microbial Identification System (MIDI) and identification of fatty acids was made by using the Aerobe (TSBA, 6.0 version) database. The predominant fatty acids of strain $\mathrm{A} 648^{\mathrm{T}}$ were $18: 1 \omega 9 c$ $(19.6 \%)$, summed feature $3(16: 1 \omega 7 c$ and/or $16: 1 \omega 6 c$, $15.9 \%), \quad 16: 0(10.6 \%)$ and $12: 0(6.4 \%)$. Fatty acid analysis also indicated that strain $\mathrm{A} 648^{\mathrm{T}}$ contained summed feature 2, comprising 14:0 3-OH and/or 16:1 iso $1(4.4 \%), 12: 03-\mathrm{OH}(4.2 \%)$ and $12: 02-\mathrm{OH}(2.2 \%)$ (Table 1). The presence of 12:0, 12:0 3-OH, 16:0, $18: 1 \omega 9 c$ and summed feature 3 fatty acids is a feature shown by most of the members of the genus Acinetobacter (Kim et al., 2008). A significant difference was observed in terms of the percentage of each type of cellular fatty acid between that found in strain $\mathrm{A} 648^{\mathrm{T}}$ and those in the other recognized species of this genus (Kämpfer, 1993). This profile thus confirms that $\mathrm{A} 648^{\mathrm{T}}$ represents a novel species of the genus Acinetobacter.

For the polyamine analysis, polar lipid profile and detection of quinones, the culture was inoculated in LB broth and incubated at $28{ }^{\circ} \mathrm{C}$ for $24 \mathrm{~h}$ and was then lyophilized to obtain the dry cell mass. Polyamines were then extracted as described by Busse \& Auling (1988) and analysed by one dimensional TLC (Silica gel 60 F254, $20 \times 20 \mathrm{~cm}$; Merck). Some members of the genus Acinetobacter have been 


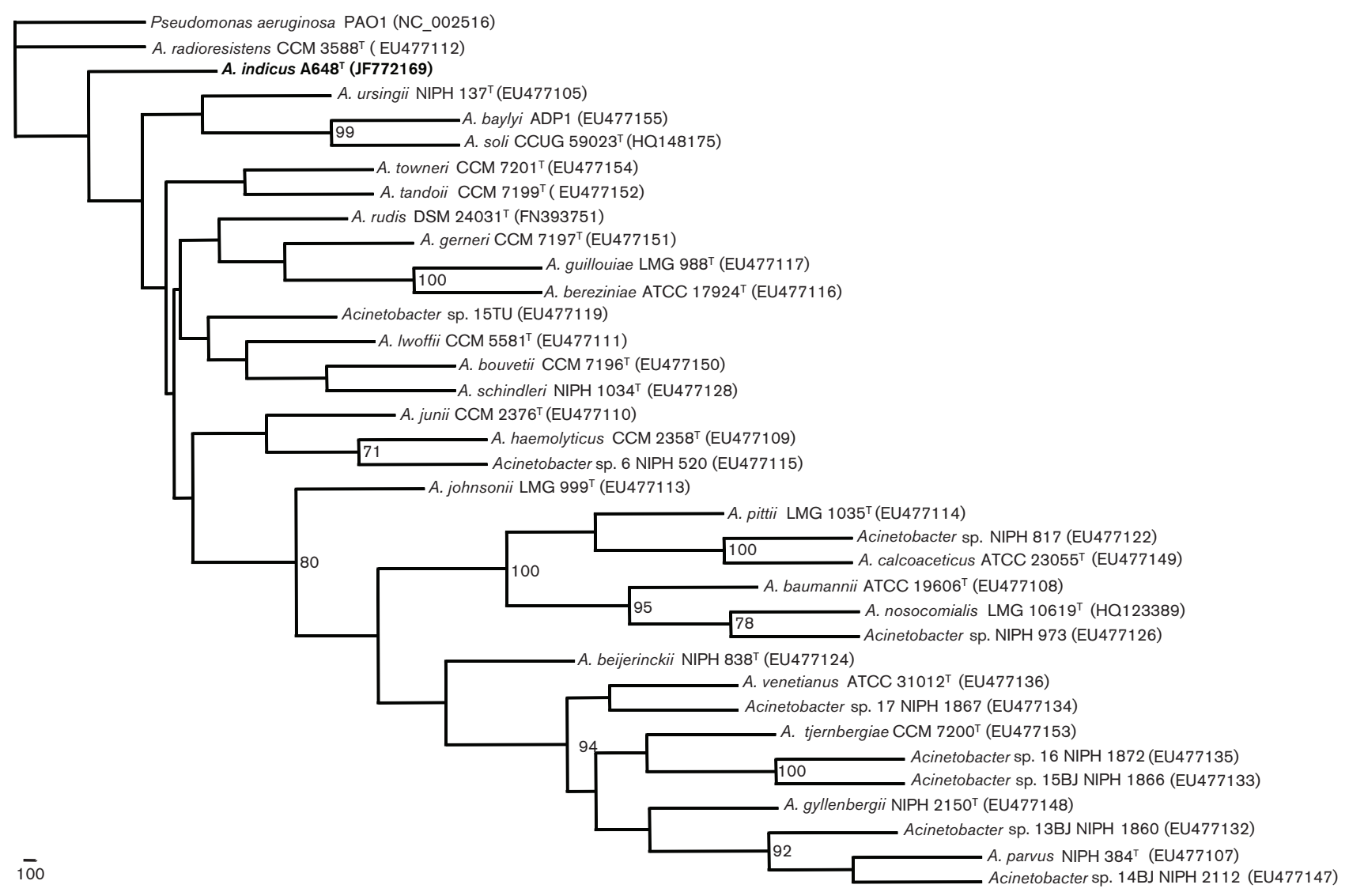

Fig. 2. Phylogenetic tree based on two concatenated variable zones of the $r p o B$ gene sequences of strain $A 648^{\top}$ and representative members of the genus Acinetobacter. The tree was constructed using the NJ method. Bootstrap values $>70 \%$ are indicated (based on 1000 resamplings). GenBank accession numbers are given in parentheses. Pseudomonas aeruginosa PAO1 (GenBank accession no. NC_002516) was used as the out-group. Bar, 0.01 nucleotide substitutions per site.

reported to possess a characteristic polyamine distribution pattern with 1,3-diaminopropane (DAP) as a major component and very little putrescine, spermidine or spermine (Busse \& Auling, 1988; Yamamoto et al., 1991). Since DAP has been reported to be the characteristic main polyamine compound produced by many members of the genus Acinetobacter, it has also been used as a biomarker for the identification of the genus (Auling et al., 1991). On analysis, the major polyamine of strain $A 648^{\mathrm{T}}$ was found to be DAP and moderate amounts of putrescine, spermidine and spermine were also detected, demonstrating that strain $\mathrm{A} 648^{\mathrm{T}}$ belongs to the genus Acinetobacter.

Polar lipid analysis of strain $\mathrm{A} 648^{\mathrm{T}}$ was performed by two dimensional TLC, as described by Gupta et al. (2009). The total lipid profile was detected by spraying aqueous primuline solution, which consisted of $100 \mu \mathrm{l} 1 \%$ primuline solution and $100 \mu \mathrm{l}$ water that was added to $10 \mathrm{ml}$ acetone, with the solution being mixed well. This solution was sprayed on TLC plates and spots were visualized under UV light. The polar lipid analysis of strain $\mathrm{A} 648^{\mathrm{T}}$ revealed the presence of phosphatidylethanolamine, phosphatidylglycerol, diphosphatidylglycerol and phosphatidylcholine
(Fig. S3). This profile was similar to those of the recently described strains of the genus Acinetobacter (Lee \& Lee, 2010; Aluyi et al., 1992).

Quinones were extracted according to the method explained by Dadhwal et al. (2009) and analysed by reverse-phase TLC, according to Collins \& Jones (1980). Ubiquinone Q-9 was detected as the respiratory quinone in strain $\mathrm{A} 648^{\mathrm{T}}$. The presence of this quinone system supported the fact that strain $\mathrm{A} 648^{\mathrm{T}}$ belongs to the genus Acinetobacter (Kim et al., 2008; Nishimura et al., 1988; Collins \& Jones, 1981). All these chemotaxonomic data suggest that strain $\mathrm{A} 648^{\mathrm{T}}$ represents a novel species of the genus Acinetobacter.

The DNA G $+\mathrm{C}$ content of strain $\mathrm{A} 648^{\mathrm{T}}$, as determined by using the thermal denaturation method of Gonzalez \& Saiz-Jimenez (2002), was found to be $40.4 \mathrm{~mol} \%$, which was within the range as reported for the genus by VazMoreira et al. (2011).

The colour, size and shape of cells of strain $\mathrm{A} 648^{\mathrm{T}}$ were observed on LB agar plates incubated at $28{ }^{\circ} \mathrm{C}$ for $24 \mathrm{~h}$. Gram staining was performed using HiMedia Gram 
Table 1. Cellular fatty acid profile of strain $A 648^{\top}$ and the type strains of closely related members of the genus Acinetobacter (16S rRNA gene sequence similarity greater than $97 \%$ )

1, Strain $\mathrm{A} 648^{\mathrm{T}} ; 2$, A. radioresistens DSM $6976^{\mathrm{T}} ; 3$, A. venetianus ATCC $31012^{\mathrm{T}}$; 4, A. baumannii LMG $1041^{\mathrm{T}}$; 5, A. parvus LMG $21765^{\mathrm{T}} ; 6$, A. junii LMG $998^{\mathrm{T}} ; 7$, A. soli JCM $15062^{\mathrm{T}}$. The data were generated for all strains by streaking them on LB agar at $28{ }^{\circ} \mathrm{C}$ for 48 h. Values are percentages of total fatty acids. -, Not detected.

\begin{tabular}{|lccccccc|}
\hline Fatty acid & $\mathbf{1}$ & $\mathbf{2}$ & $\mathbf{3}$ & $\mathbf{4}$ & $\mathbf{5}$ & $\mathbf{6}$ & $\mathbf{7}$ \\
\hline $10: 0$ & 0.8 & 0.5 & 2.5 & \multicolumn{1}{c}{-} & - & 2.5 & 0.4 \\
$12: 0$ & 6.4 & 11.2 & 5.1 & 9.7 & 5.9 & 3.8 & 10.5 \\
$13: 0$ & 1.2 & \multicolumn{1}{c}{-} & \multicolumn{1}{c}{-} & 0.4 & - & 0.2 & - \\
$14: 0$ & 1.7 & 1.3 & 0.7 & 0.7 & 1.7 & 1.3 & 0.6 \\
$16: 0$ & 10.6 & 15.6 & 18.2 & 17.6 & 16.8 & 16.3 & 20.2 \\
$17: 0$ & 1.5 & 1.2 & 2.4 & 2.4 & 0.7 & 1.7 & 0.5 \\
$18: 0$ & 4.6 & 1.5 & 0.7 & 0.9 & 1.0 & 2.3 & 0.9 \\
$12: 02-\mathrm{OH}$ & 2.2 & 0.9 & 7.6 & 4.6 & 3.9 & 7.6 & 3.9 \\
$12: 03-\mathrm{OH}$ & 4.2 & 6.5 & 9.2 & 5.9 & 5.6 & 8.9 & 6.5 \\
$17: 1 \omega 8 c$ & 1.8 & 2.2 & 2.9 & 3.0 & 1.7 & 1.0 & 0.3 \\
$18: 1 \omega 9 c$ & 19.6 & 25.8 & 25.2 & 34.9 & 38.2 & 28.1 & 36.6 \\
$17: 0$ & 1.2 & - & - & 0.2 & - & 0.2 & 0.2 \\
anteiso & & & & & & & \\
Summed & & & & & & & \\
feature* & & & & & & & \\
2 & 4.4 & 2.4 & 0.4 & 6.6 & - & 0.4 & 4.0 \\
3 & 15.9 & 12.3 & 22.4 & 11.3 & 23.8 & 23.5 & 12.9 \\
5 & - & 15.8 & - & - & - & - & - \\
8 & 1.4 & 1.5 & 1.0 & - & - & - & - \\
& & & & & & & \\
\hline
\end{tabular}

*Summed features are groups of two or three fatty acids that cannot be separated using the MIDI system. Summed feature 2 consists of $16: 1$ iso 1 and/or 14:03-OH, summed feature 3 consists of $16: 1 \omega 7 c$ and/or $16: 1 \omega 6 c$, summed feature 5 consists of $18: 0$ ante and/or $18: 2 \omega 6,9 c$ and summed feature 8 consists of $18: 1 \omega 6 c$ and/or $18: 1 \omega 7 c$.

staining kit (HiMedia). The morphology of colonies, streaked on LB agar plates and incubated for $24 \mathrm{~h}$, was examined under a light microscope (model 2000; Motic). Growth at different temperatures, $\mathrm{pH}$ and $\mathrm{NaCl}$ concentrations was determined as described by Arden-Jones et al. (1979). In order to determine the growth at different temperatures, strain $\mathrm{A} 648^{\mathrm{T}}$ was streaked on $\mathrm{LB}$ agar plates and incubated at $4,10,28,37,42,44$ and $55{ }^{\circ} \mathrm{C}$ for 4 5 days. Growth was studied at different $\mathrm{pH}$ values (range of $\mathrm{pH} 4-12)$ and salt concentrations $(1-10 \%, \mathrm{w} / \mathrm{v}, \mathrm{NaCl})$ in $\mathrm{LB}$ broth at $28{ }^{\circ} \mathrm{C}$. Strain $\mathrm{A} 648^{\mathrm{T}}$ was cultured to test its growth on tryptic soy agar (TSA) and nutrient agar (NA) at $28{ }^{\circ} \mathrm{C}$. The motility of strain $\mathrm{A} 648^{\mathrm{T}}$ cells was checked on motility agar medium (Farmer, 1999). Cell morphology and the presence or absence of flagella was examined by taking a loopful of culture grown until stationary phase (at $28{ }^{\circ} \mathrm{C}$ for $24 \mathrm{~h}$ ), suspending it in a fixative and washing with a phosphate buffer, and then observing the sample under a transmission electron microscope (TEM; Morgagni 269D; Fei). The cells were then negatively stained with $0.5 \%$ uranyl acetate and the grids were observed under a TEM (All India Institute of Medical Sciences) (Fig. S4).

Haemolysis was tested on Columbia agar plates supplemented with $5 \%$ sheep blood (HiMedia) within $48 \mathrm{~h}$ of incubation. Acid production from carbohydrates and other substrates was tested using the basal mineral medium of Cruze et al. (1979), supplemented with filter-sterilized carbon source solutions at final concentrations of $0.2 \%$ (w/v, carbohydrates) and $0.1 \%$ (w/v, other substrates), as described by Nishimura et al. (1988). The basal medium consisted of the following $\left(\mathrm{l}^{-1}\right): 10 \mathrm{~g} \mathrm{KH}_{2} \mathrm{PO}_{4}, 5 \mathrm{~g}$ $\mathrm{Na}_{2} \mathrm{HPO}_{4}, 2 \mathrm{~g}\left(\mathrm{NH}_{4}\right)_{2} \mathrm{SO}_{4}, 0.2 \mathrm{~g} \mathrm{MgSO}{ }_{4} .7 \mathrm{H}_{2} \mathrm{O}, 0.001 \mathrm{~g}$ $\mathrm{CaCl}_{2} \cdot 2 \mathrm{H}_{2} \mathrm{O}$ and $0.001 \mathrm{~g} \mathrm{FeSO}_{4} \cdot 7 \mathrm{H}_{2} \mathrm{O}(\mathrm{pH}$ 7.0). The tubes were incubated at $28{ }^{\circ} \mathrm{C}$ and growth on carbon sources was evaluated after 2, 4, 6 and 10 days.

Hydrolysis of aesculin, casein, gelatin, DNA, and Tween 20 and 80 was tested as described by Arden-Jones et al. (1979). $\beta$-Galactosidase activity was observed using HiMedia ONPG discs. The catalase test was carried out using $3 \%$ (v/v) hydrogen peroxide ascertained by McCarthy \& Cross (1984). The nitrate reduction test was performed as described by Smibert \& Krieg (1994). Other physiological tests were carried out as described by Collins et al. (1989).

Strain $\mathrm{A} 648^{\mathrm{T}}$ is a Gram-negative, non-motile, aerobic bacterium. Strain $\mathrm{A} 648^{\mathrm{T}}$ appeared light yellow, convex and smooth with circular colonies after $24 \mathrm{~h}$ of incubation at $28{ }^{\circ} \mathrm{C}$ on LB agar. Strain $\mathrm{A} 648^{\mathrm{T}}$ was negative in tests for oxidase activity and positive for catalase. Several morphological and phenotypic characteristics, as observed in this study, differentiated strain $\mathrm{A}_{648}{ }^{\mathrm{T}}$ from related members of the genus Acinetobacter (Tables 2 and S2). Selected phenotypic characteristics of strain $A 648^{\mathrm{T}}$ determined in this study were also compared with the 26 validly named species (Table 2). The study revealed that strain $A 648^{\mathrm{T}}$ is a non-haemolytic Acinetobacter strain, which has the ability to utilize benzoate, ethanol, DL-lactate, phenylacetate, but not mannose, D-fructose, raffinose, cellobiose, xylose, mannitol, meso-inositol, sucrose, sorbose, citraconate, adipate, putrescine, L-aspartate, L-histidine, L-arginine, L-ornithine, L-lysine, $\beta$-alanine or D-malate as a single carbon source (Tables 2 and S2). Thus, based on the phylogenetic, biochemical and genotypic analyses, we conclude that strain $A 648^{\mathrm{T}}$ represents a novel species of the genus Acinetobacter for which the name Acinetobacter indicus sp. nov. is proposed.

\section{Description of Acinetobacter indicus sp. nov.}

Acinetobacter indicus (in'di.cus. L. masc. adj. indicus Indian, of or belonging to India).

Gram-negative, non-motile, non-spore-forming, aerobic bacterium. Colonies are light yellow in colour, small, entire, smooth, circular, convex and opaque. Optimum growth is observed within $24 \mathrm{~h}$ on LB medium at $28{ }^{\circ} \mathrm{C}$. Grows well on LB, NA and TSA. The colony size obtained 
Table 2. Distinctive characteristics of the different species of members of the genus Acinetobacter

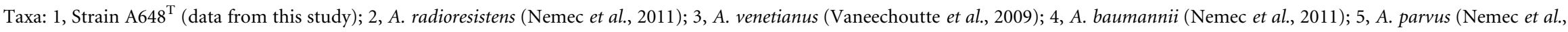

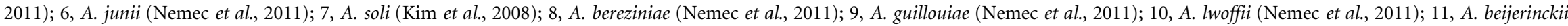

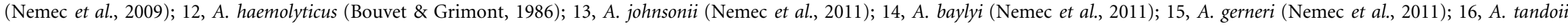

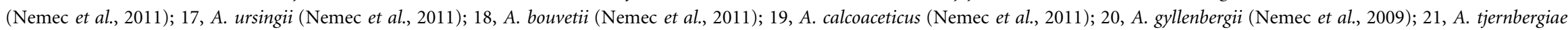

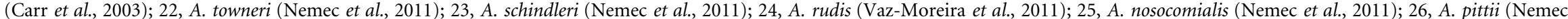

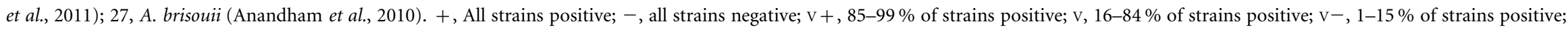
$\mathrm{NA}$, not available; D, doubtful or weak reaction.

\begin{tabular}{|c|c|c|c|c|c|c|c|c|c|c|c|c|c|c|c|c|c|c|c|c|c|c|c|c|c|c|c|}
\hline & 1 & 2 & 3 & 4 & 5 & 6 & 7 & 8 & 9 & 10 & 11 & 12 & 13 & 14 & 15 & 16 & 17 & 18 & 19 & 20 & 21 & 22 & 23 & 24 & 25 & 26 & 27 \\
\hline No. of isolates & 1 & 6 & 5 & 25 & 10 & 4 & 1 & 16 & 17 & 8 & 15 & 23 & 8 & 5 & 1 & 1 & 15 & 1 & 11 & 9 & 1 & 2 & 14 & 2 & 20 & 20 & 1 \\
\hline \multicolumn{28}{|l|}{ Growth at } \\
\hline $44^{\circ} \mathrm{C}$ & - & - & - & + & - & - & - & - & - & - & - & - & - & - & - & - & - & - & - & - & - & - & - & - & $\mathrm{v}+$ & $\mathrm{v}-$ & - \\
\hline $41{ }^{\circ} \mathrm{C}$ & + & + & - & + & - & $\mathrm{V}$ & + & - & - & - & - & - & - & $\mathrm{V}$ & - & - & - & - & $\mathrm{v}-$ & - & - & NA & $\mathrm{v}+$ & - & + & + & - \\
\hline $37{ }^{\circ} \mathrm{C}$ & + & + & + & + & + & + & + & + & V & + & + & + & $\mathrm{V}$ & + & + & + & $\mathrm{v}+$ & $\mathrm{D}$ & $\mathrm{v}+$ & $\mathrm{v}+$ & - & + & + & + & + & + & + \\
\hline Haemolytic activity & - & - & + & - & - & $\mathrm{V}$ & - & - & - & - & + & + & - & - & - & - & - & - & - & + & - & - & - & - & - & - & NA \\
\hline Acidification of D-glucose & - & - & - & + & - & - & + & $\mathrm{v}+$ & - & $\mathrm{v}-$ & - & $\mathrm{V}$ & - & + & + & - & - & - & $\mathrm{v}+$ & - & - & - & - & - & + & $\mathrm{v}+$ & - \\
\hline \multicolumn{28}{|l|}{ Utilization of: } \\
\hline Adipate & - & + & $\mathrm{V}$ & $\mathrm{v}+$ & - & - & + & $\mathrm{v}$ & + & $\mathrm{v}+$ & - & $\mathrm{NA}$ & - & + & + & - & + & - & + & + & - & - & $\mathrm{V}$ & - & $\mathrm{v}+$ & + & - \\
\hline$\beta$-Alanine & - & - & - & + & - & - & $\mathrm{NA}$ & + & $\mathrm{v}+$ & - & - & - & - & - & + & - & - & - & $\mathrm{v}+$ & + & - & - & - & $\mathrm{NA}$ & $\mathrm{v}+$ & $\mathrm{v}+$ & + \\
\hline 4-Aminobutyrate & $\mathrm{D}$ & + & + & + & - & $\mathrm{V}$ & $\mathrm{NA}$ & + & $\mathrm{v}+$ & $\mathrm{v}+$ & + & + & $\mathrm{v}$ & + & + & + & - & - & + & $\mathrm{v}-$ & - & - & - & $\mathrm{NA}$ & + & + & - \\
\hline L-Arabinose & $\mathrm{D}$ & - & - & $\mathrm{V}$ & - & - & + & - & - & - & - & $\mathrm{NA}$ & - & - & - & - & - & - & $\mathrm{V}$ & - & NA & - & - & - & + & $\mathrm{v}+$ & - \\
\hline L-Arginine & - & + & + & + & - & + & $\mathrm{NA}$ & - & - & - & - & + & $\mathrm{v}$ & + & - & + & - & - & + & + & + & - & - & - & + & + & NA \\
\hline L-Aspartate & - & - & - & + & - & $\mathrm{V}$ & + & + & + & - & + & V & $\mathrm{v}$ & + & + & + & $\mathrm{v}+$ & - & + & - & V & - & - & - & + & + & NA \\
\hline Benzoate & + & + & + & $\mathrm{V}$ & - & + & $\mathrm{NA}$ & + & $\mathrm{v}+$ & $\mathrm{v}+$ & - & $\mathrm{NA}$ & + & + & + & + & $\mathrm{V}$ & + & + & + & NA & + & $\mathrm{v}+$ & + & $\mathrm{v}+$ & $\mathrm{v}+$ & NA \\
\hline 2,3-Butanediol & $\mathrm{D}$ & + & - & + & - & - & $\mathrm{NA}$ & + & + & - & - & - & $\mathrm{v}$ & + & + & + & - & - & + & - & - & $\mathrm{v}$ & $\mathrm{V}$ & + & $\mathrm{v}+$ & $\mathrm{v}+$ & NA \\
\hline Citraconate & - & - & - & $\mathrm{v}$ & - & - & $\mathrm{NA}$ & - & - & - & - & $\mathrm{NA}$ & - & - & - & - & - & - & - & - & NA & - & - & $\mathrm{NA}$ & - & - & NA \\
\hline Citrate (Simmons) & - & - & + & + & - & $\mathrm{V}$ & + & + & + & $\mathrm{v}-$ & + & $\mathrm{v}+$ & $\mathrm{v}$ & + & + & + & + & + & $\mathrm{v}+$ & + & - & - & $\mathrm{V}$ & + & + & + & - \\
\hline Ethanol & + & + & + & $\mathrm{v}+$ & + & $\mathrm{V}$ & $\mathrm{NA}$ & + & + & + & + & $\mathrm{v}+$ & + & + & + & + & + & + & $\mathrm{v}+$ & $\mathrm{V}$ & $\mathrm{NA}$ & + & $\mathrm{v}+$ & + & + & + & NA \\
\hline D-Glucose & - & - & - & - & - & - & + & - & - & - & - & $\mathrm{NA}$ & - & + & - & - & - & - & - & - & $\mathrm{NA}$ & - & - & - & - & - & - \\
\hline L-Histidine & - & - & + & $\mathrm{v}+$ & - & $\mathrm{V}$ & NA & $\mathrm{v}+$ & $\mathrm{v}+$ & - & + & $\mathrm{v}+$ & - & - & - & + & - & + & + & + & + & - & - & + & + & + & - \\
\hline DL-Lactate & + & + & - & + & - & + & + & + & + & + & - & - & + & + & + & + & + & + & + & + & NA & + & + & $\mathrm{NA}$ & + & + & + \\
\hline D-Malate & - & - & + & $\mathrm{v}+$ & - & $\mathrm{V}$ & + & $\mathrm{v}+$ & + & $\mathrm{V}-$ & + & $\mathrm{v}+$ & - & $\mathrm{D}$ & - & + & $\mathrm{v}+$ & - & $\mathrm{D}$ & + & $\mathrm{NA}$ & $\mathrm{v}$ & $\mathrm{v}+$ & $\mathrm{NA}$ & + & $\mathrm{v}+$ & NA \\
\hline L-Ornithine & - & - & - & $\mathrm{V}$ & $\mathrm{V}$ & - & $\mathrm{NA}$ & - & - & - & - & - & $\mathrm{v}-$ & - & - & + & - & - & + & v & $\mathrm{NA}$ & - & - & $\mathrm{NA}$ & $\mathrm{v}+$ & $\mathrm{v}+$ & NA \\
\hline Phenylacetate & + & + & - & $\mathrm{V}$ & - & - & + & $\mathrm{v}$ & V & $\mathrm{v}+$ & - & - & - & - & + & + & - & - & + & + & - & - & - & + & $\mathrm{v}+$ & $\mathrm{v}$ & + \\
\hline Putrescine & - & V & - & $\mathrm{v}+$ & - & - & $\mathrm{NA}$ & - & - & - & - & $\mathrm{NA}$ & - & - & - & + & - & - & + & - & - & - & - & - & $\mathrm{v}+$ & + & NA \\
\hline D-Ribose & $\mathrm{D}$ & - & NA & $\mathrm{V}$ & - & - & + & - & - & - & - & $\mathrm{NA}$ & - & - & - & - & - & - & V & - & NA & - & - & - & $\mathrm{V}$ & $\mathrm{v}$ & - \\
\hline
\end{tabular}


is $0.5 \mathrm{~mm}$ in diameter, after $24 \mathrm{~h}$ of incubation at $28{ }^{\circ} \mathrm{C}$. Growth is observed in $0-5 \%(\mathrm{w} / \mathrm{v}) \mathrm{NaCl}$, over $\mathrm{pH} 7-9$ and at a temperature range of $22-42{ }^{\circ} \mathrm{C}$. The optimal growth is observed at $28{ }^{\circ} \mathrm{C}, \mathrm{pH} 7.0$ and $1 \%(\mathrm{w} / \mathrm{v}) \mathrm{NaCl}$. Tween 20 and 80 are hydrolysed, but not aesculin, casein, gelatin or DNA. The $\mathrm{H}_{2} \mathrm{~S}$ production test is negative. Not flagellated. Cells are coccobacilli in shape, with a cell size of $1.0 \mu \mathrm{m}$ as analysed by electron microscopy. The nitrate reduction test is positive. Utilizes ethanol and acetate as sole sources of carbon in basal medium and negative result for the haemolysis of sheep blood. Assimilation of adipate, $\beta$ alanine, L-aspartate, L-ornithine, L-arginine, L-lysine and Lhistidine is not observed, but the assimilation of benzoate and DL-lactate is observed. The major fatty acids are $18: 1 \omega 9 c$ and summed feature 3, comprising $(16: 1 \omega 7 c$ and/or $16: 1 \omega 6 c) 16: 0$ and $12: 0$. The major polyamine is 1,3-diaminopropane. The respiratory quinone detected is ubiquinone Q-9. The predominant polar lipids are diphosphatidylglycerol, phosphatidylethanolamine, phosphatidylglycerol and phosphatidylcholine.

The type strain, $\mathrm{A} 648^{\mathrm{T}}\left(=\operatorname{DSM} 25388^{\mathrm{T}}=\mathrm{CCM} 7832^{\mathrm{T}}\right)$, was isolated from a $\mathrm{HCH}$ dump site at Ummari Village, Lucknow, India. The DNA G + C content is $40.4 \mathrm{~mol} \%$.

\section{Acknowledgements}

This research was supported by funds from the Department of Biotechnology (DBT) and the DU/DST-PURSE Grant, Government of India. J. M., S. A. and S. J. acknowledge the Council of Scientific and Industrial Research and the DBT for providing research fellowships. We also acknowledge the Sophisticated Analytical Instrumentation Facility, the Department of Science and Technology and the Department of Anatomy. Special thanks are extended to Dr Mario Vaneechoutte and Dr Alexandr Nemec who provided $A$. venetianus RAG $^{\mathrm{T}}$ and $A$. parvus NIPH $384^{\mathrm{T}}$, respectively. We also thank J. P. Euzéby for etymological advice.

\section{References}

Aluyi, H. S., Boote, V., Drucker, D. B., Wilson, J. M. \& Ling, Y. H. (1992). Analysis of polar lipids from some representative enterobacteria, Plesiomonas and Acinetobacter by fast atom bombardment-mass spectrometry. J Appl Bacteriol 73, 426-432.

Anandham, R., Weon, H.-Y., Kim, S.-J., Kim, Y.-S., Kim, B.-Y. \& Kwon, S.-W. (2010). Acinetobacter brisouii sp. nov., isolated from a wetland in Korea. J Microbiol 48, 36-39.

Arden-Jones, M. P., McCarthy, A. J. \& Cross, T. (1979). Taxonomic and serologic studies on Micropolyspora faeni and Micropolyspora strains from soil bearing the specific epithet rectivirgula. J Gen Microbiol 115, 343-354.

Auling, G., Pilz, F., Busse, H. J., Karrasch, S., Streichan, M. \& Schön, G. (1991). Analysis of the polyphosphate-accumulating microflora in phosphorus-eliminating, anaerobic-aerobic activated sludge systems by using diaminopropane as a biomarker for rapid estimation of Acinetobacter spp. Appl Environ Microbiol 57, 3585-3592.

Bouvet, P. J. M. \& Grimont, P. A. D. (1986). Taxonomy of the genus Acinetobacter with the recognition of Acinetobacter baumannii sp. nov., Acinetobacter haemolyticus sp. nov., Acinetobacter johnsonii sp. nov. and Acinetobacter junii sp. nov. and emended descriptions of
Acinetobacter calcoaceticus and Acinetobacter lwoffii. Int J Syst Bacteriol 36, 228-240.

Bouvet, P. J. M. \& Jeanjean, S. (1989). Delineation of new proteolytic genomic species in the genus Acinetobacter. Res Microbiol 140, 291299.

Brisou, J. \& Prevot, A. R. (1954). Etudes de systématique bactérienne. $\mathrm{X}$. Révision des especes réunies dans le genre Achromobacter. Ann Inst Pasteur (Paris) 86, 722-728.

Busse, J. \& Auling, G. (1988). Polyamine pattern as a chemotaxonomic marker within the Proteobacteria. Syst Appl Microbiol 11, $1-8$.

Carr, E. L., Kämpfer, P., Patel, B. K. C., Gürtler, V. \& Seviour, R. J. (2003). Seven novel species of Acinetobacter isolated from activated sludge. Int J Syst Evol Microbiol 53, 953-963.

Chun, J., Lee, J. H., Jung, Y., Kim, M., Kim, S., Kim, B. K. \& Lim, Y. W. (2007). EzTaxon: a web-based tool for the identification of prokaryotes based on $16 \mathrm{~S}$ ribosomal RNA gene sequences. Int J Syst Evol Microbiol 57, 2259-2261.

Collins, M. D. \& Jones, D. (1980). Lipids in the classification and identification of coryneform bacteria containing peptidoglycan based on 2,4-diamino butyric acid (DAB). J Appl Bacteriol 48, 459-470.

Collins, M. D. \& Jones, D. (1981). Distribution of isoprenoid quinone structural types in bacteria and their taxonomic implication. Microbiol Rev 45, 316-354.

Collins, C. H., Lyne, P. M. \& Grange, J. M. (1989). Microbiological Methods, 6th edn. London: Butterworth.

Cruze, J. A., Singer, J. T. \& Finnerty, W. R. (1979). Conditions for quantitative transformation in Acinetobacter calcoaceticus. Curr Microbiol 3, 129-132.

Dadhwal, M., Jit, S., Kumari, H. \& Lal, R. (2009). Sphingobium chinhatense sp. nov., a hexachlorocyclohexane $(\mathrm{HCH})$-degrading bacterium isolated from an $\mathrm{HCH}$ dumpsite. Int $J$ Syst Evol Microbiol 59, 3140-3144.

Farmer, J. J., III (1999). Enterobacteriaceae: introduction and identification. In Manual of Clinical Microbiology, 7th edn, pp. 448-452. Edited by P. R. Murray, E. J. Baron, M. A. Pfaller, F. C. Tenover \& R. H. Yolken. Washington, DC: American Society for Microbiology.

Felsenstein, J. (1981). Evolutionary trees from DNA sequences: a maximum likelihood approach. J Mol Evol 17, 368-376.

Felsenstein, J. (1993). PHYLIP (phylogeny inference package), version 3.5c. Distributed by the author. Department of Genome Sciences, University of Washington, Seattle, USA.

Gerner-Smidt, P. \& Tjernberg, I. (1993). Acinetobacter in Denmark: II. Molecular studies of the Acinetobacter calcoaceticus-Acinetobacter baumannii complex. APMIS 101, 826-832.

Gonzalez, J. M. \& Saiz-Jimenez, C. (2002). A fluorimetric method for the estimation of $\mathrm{G}+\mathrm{C}$ mol\% content in microorganisms by thermal denaturation temperature. Environ Microbiol 4, 770-773.

Gupta, S. K., Lal, D. \& Lal, R. (2009). Novosphingobium panipatense sp. nov. and Novosphingobium mathurense sp. nov., from oil-contaminated soil. Int J Syst Evol Microbiol 59, 156-161.

Jit, S., Dadhwal, M., Prakash, O. \& Lal, R. (2008). Flavobacterium lindanitolerans sp. nov., isolated from hexachlorocyclohexane-contaminated soil. Int J Syst Evol Microbiol 58, 1665-1669.

Jit, S., Dadhwal, M., Kumari, H., Jindal, S., Kaur, J., Lata, P., Niharika, N., Lal, D., Garg, N. \& other authors (2011). Evaluation of hexachlorocyclohexane contamination from the last lindane production plant operating in India. Environ Sci Pollut Res Int 18, 586-597.

Jukes, T. \& Cantor, C. R. (1969). Evolution of protein molecules. In Mammalian Protein Metabolism, pp. 21-132. Edited by H. N. Munro. New York: Academic Press. 
Kämpfer, P. (1993). Grouping of Acinetobacter genomic species by cellular fatty acid composition. Med Microbiol Lett 2, 394-400.

Kim, D., Baik, K. S., Kim, M. S., Park, S. C., Kim, S. S., Rhee, M. S., Kwak, Y. S. \& Seong, C. N. (2008). Acinetobacter soli sp. nov., isolated from forest soil. J Microbiol 46, 396-401.

Kumar, M., Verma, M. \& Lal, R. (2008). Devosia chinhatensis sp. nov., isolated from a hexachlorocyclohexane $(\mathrm{HCH})$ dump site in India. Int J Syst Evol Microbiol 58, 861-865.

Kuykendall, L. D., Roy, M. A., O’Neill, J. J. \& Devine, T. E. (1988). Fatty acids, antibiotic resistance and deoxyribonucleic acid homology groups of Bradyrhizobium japonicum. Int J Syst Bacteriol 38, 358361.

La Scola, B., Gundi, V. A., Khamis, A. \& Raoult, D. (2006). Sequencing of the $r p o B$ gene and flanking spacers for molecular identification of Acinetobacter species. J Clin Microbiol 44, 827-832.

Lal, R., Pandey, G., Sharma, P., Kumari, K., Malhotra, S., Pandey, R., Raina, V., Kohler, H. P.-E., Holliger, C. \& other authors (2010). Biochemistry of microbial degradation of hexachlorocyclohexane and prospects for bioremediation. Microbiol Mol Biol Rev 74, 58-80.

Lee, H. J. \& Lee, S. S. (2010). Acinetobacter kyonggiensis sp. nov., a $\beta$ glucosidase-producing bacterium, isolated from sewage treatment plant. J Microbiol 48, 754-759.

McCarthy, A. J. \& Cross, T. (1984). A taxonomic study of Thermomonospora and other monosporic actinomycetes. J Gen Microbiol 130, 5-25.

Miller, L. T. (1982). Single derivatization method for routine analysis of bacterial whole-cell fatty acid methyl esters, including hydroxy acids. J Clin Microbiol 16, 584-586.

Nemec, A., De Baere, T., Tjernberg, I., Vaneechoutte, M., van der Reijden, T. J. K. \& Dijkshoorn, L. (2001). Acinetobacter ursingii sp. nov. and Acinetobacter schindleri sp. nov., isolated from human clinical specimens. Int J Syst Evol Microbiol 51, 1891-1899.

Nemec, A., Dijkshoorn, L., Cleenwerck, I., De Baere, T., Janssens, D., Van Der Reijden, T. J. K., Jezek, P. \& Vaneechoutte, M. (2003). Acinetobacter parvus sp. nov., a small-colony-forming species isolated from human clinical specimens. Int J Syst Evol Microbiol 53, 15631567.

Nemec, A., Musilek, M., Maixnerová, M., De Baere, T., van der Reijden, T. J. K., Vaneechoutte, M. \& Dijkshoorn, L. (2009). Acinetobacter beijerinckii sp. nov. and Acinetobacter gyllenbergii sp. nov., haemolytic organisms isolated from humans. Int J Syst Evol Microbiol 59, 118-124.

Nemec, A., Musilek, M., Šedo, O., De Baere, T., Maixnerová, M., van der Reijden, T. J. K., Zdráhal, Z., Vaneechoutte, M. \& Dijkshoorn, L. (2010). Acinetobacter bereziniae sp. nov. and Acinetobacter guillouiae sp. nov., to accommodate Acinetobacter genomic species 10 and 11, respectively. Int J Syst Evol Microbiol 60, 896-903.

Nemec, A., Krizova, L., Maixnerova, M., van der Reijden, T. J., Deschaght, P., Passet, V., Vaneechoutte, M., Brisse, S. \& Dijkshoorn, L. (2011). Genotypic and phenotypic characterization of the Acinetobacter calcoaceticus-Acinetobacter baumannii complex with the proposal of Acinetobacter pittii sp. nov. (formerly Acinetobacter genomic species 3) and Acinetobacter nosocomialis sp. nov. (formerly Acinetobacter genomic species 13TU). Res Microbiol 162, 393-404.
Nishimura, Y., Ino, T. \& lizuka, H. (1988). Acinetobacter radioresistens sp. nov. isolated from cotton and soil. Int J Syst Evol Microbiol 38, 209-211.

Nowak, A. \& Kur, J. (1996). Differentiation of seventeen genospecies of Acinetobacter by multiplex polymerase chain reaction and restriction fragment length polymorphism analysis. Mol Cell Probes 10, 405-411.

Page, R. D. M. (1996). TreeView: an application to display phylogenetic trees on personal computers. Comput Appl Biosci 12, 357-358.

Saitou, N. \& Nei, M. (1987). The neighbor-joining method: a new method for reconstructing phylogenetic trees. Mol Biol Evol 4, 406425.

Singh, A. \& Lal, R. (2009). Sphingobium ummariense sp. nov., a hexachlorocyclohexane $(\mathrm{HCH})$-degrading bacterium, isolated from HCH-contaminated soil. Int J Syst Evol Microbiol 59, 162-166.

Smibert, R. M. \& Krieg, N. R. (1994). Phenotypic characterization. In Methods for General and Molecular Bacteriology, pp. 607-654. Edited by P. Gerhardt, R. G. E. Murray, W. A. Wood \& N. R. Krieg. Washington, D.C.: American Society for Microbiology.

Stackebrandt, E. \& Goebel, B. M. (1994). Taxonomic note: a place for DNA-DNA reassociation and $16 \mathrm{~S}$ rRNA sequence analysis in the present species definition in bacteriology. Int J Syst Bacteriol 44, 846849.

Takahashi, K. \& Nei, M. (2000). Efficiencies of fast algorithms of phylogenetic inference under the criteria of maximum parsimony, minimum evolution, and maximum likelihood when a large number of sequences are used. Mol Biol Evol 17, 1251-1258.

Thompson, J. D., Gibson, T. J., Plewniak, F., Jeanmougin, F. \& Higgins, D. G. (1997). The CLUSTAL_X windows interface: flexible strategies for multiple sequence alignment aided by quality analysis tools. Nucleic Acids Res 25, 4876-4882.

Tjernberg, I. \& Ursing, J. (1989). Clinical strains of Acinetobacter classified by DNA-DNA hybridization. APMIS 97, 595-605.

Vaneechoutte, M., Tjernberg, I., Baldi, F., Pepi, M., Fani, R., Sullivan, E. R., van der Toorn, J. \& Dijkshoorn, L. (1999). Oil-degrading Acinetobacter strain RAG-1 and strains described as 'Acinetobacter venetianus sp. nov.' belong to the same genomic species. Res Microbiol 150, 69-73.

Vaneechoutte, M., Nemec, A., Musílek, M., van der Reijden, T. J., van den Barselaar, M., Tjernberg, I., Calame, W., Fani, R., De Baere, T. \& Dijkshoorn, L. (2009). Description of Acinetobacter venetianus ex Di Cello et al. 1997 sp. nov. Int J Syst Evol Microbiol 59, 1376-1381.

Vaz-Moreira, I., Novo, A., Hantsis-Zacharov, E., Lopes, A. R., Gomila, M., Nunes, O. C., Manaia, C. M. \& Halpern, M. (2011). Acinetobacter rudis sp. nov., isolated from raw milk and raw wastewater. Int J Syst Evol Microbiol 61, 2837-2843

Wayne, L. G., Brenner, D. J., Colwell, R. R., Grimont, P. A. D., Kandler, O., Krichevsky, M. I., Moore, L. H., Moore, W. E. C., Murray, R. G. E. \& other authors (1987). International Committee on Systematic Bacteriology. Report of the ad hoc committee on reconciliation of approaches to bacterial systematics. Int J Syst Bacteriol 37, 463-464.

Yamamoto, S., Tsuzaki, Y., Kishi, R. \& Nakao, H. (1991). Occurrence of L-2,4-diaminobutyrate decarboxylase activity in Acinetobacter. Chem Pharm Bull (Tokyo) 39, 2451-2453. 